\title{
Spatio-temporal characteristics and causes of changes in erosion-accretion in the Yangtze (Changjiang) submerged delta from 1982 to 2010
}

\author{
SONG Chengcheng ${ }^{1,2}$, SUN Xiaojing ${ }^{3},{ }^{*}$ WANG Jun ${ }^{1,2}$, LI Mengya $^{1,2}$, \\ ZHENG Lu ${ }^{1,2}$ \\ 1. School of Geographic Sciences, East China Normal University, Shanghai 200241, China; \\ 2. Key Laboratory of Geographic Information Science of Ministry of Education, East China Normal University, \\ Shanghai 200241, China; \\ 3. Department of Chemistry, East China Normal University, Shanghai, 200241, China
}

\begin{abstract}
The Yangtze delta's response to accelerating river damming and irrigation is a topic of global concern. This research analyzed the general erosion-accretion of the submerged delta front, the spatio-temporal changing pattern in different sub-regions, the geomorphological changes in typical cross-sections, and the geomorphological causes of the four main sub-regions (the eastern tidal wetland of Chongming-CM, the Hengsha shoal-HS, the Jiuduansha wetland-JDS, and the eastern tidal wetland of Nanhui-NH). Data sources include topographic data measured at high-resolution, sediment load at Datong Station, and the corresponding estuary construction information. Major findings are: (1) in general, the study area had slightly eroded (the erosion area ratio was $51.83 \%$ and the accretion area ratio was 48.17\%) from 1982 to 2010, and it had experienced a shift of "erosion-accretion- erosion". The spatio-temporal change of geomorphology was also significant in the eight sub-regions, excluding constant erosion in the North Channel; (2) evolution in eastern and northern CM and HS, northern JDS, and the region within the $5 \mathrm{~m}$ isobath of $\mathrm{NH}$ was dominated by vertical deposition, which was the opposite of that in southern $\mathrm{CM}$ and $\mathrm{HS}$, and the region within the 5 $m$ isobath of eastern and southern JDS; (3) on the whole, the encompassed surface areas (ESAs) of the $2 \mathrm{~m}$ and $5 \mathrm{~m}$ isobaths kept increasing, and the annual growth rates reached $10.42 \mathrm{~km}^{2} / \mathrm{yr}$ and $7.99 \mathrm{~km}^{2} / \mathrm{yr}$ respectively during 1982-2010 (however, four sub-regions exhibited disagreements), and in the whole region and all sub-regions, the ESA of the $10 \mathrm{~m}$ isobath decreased, while the ESA of the $15 \mathrm{~m}$ isobath changed slightly during the period and remained stable; (4) being less influenced by the estuarine engineering, CM was the only sub-region where the ESA of the isobath decreased in accordance with the decline of the sediment load. Major conclusions are that estuarine engineering projects play an increasingly
\end{abstract}

Received: 2014-12-20 Accepted: 2015-01-25

Foundation: National Natural Science Foundation of China, No.71373084; Global Change Scientific Research Program of China, No.2010CB951204; Innovation Program of Shanghai Municipal Education Commission, No.13ZZ035

Author: Song Chengcheng (1991-), specialized in assessment of coastal disaster risk.

E-mail: songchengcheng2008@163.com

*Corresponding author: Wang Jun (1975-), PhD and Professor, specialized in urban physical geography research and assessment of coastal disaster risk. E-mail: jwang@geo.ecnu.edu.cn 
important role in affecting the submerged delta against the macro-background of the reduction of sediment load, the change of ESA and the distribution of isobaths. Along with the accelerating construction of the Shanghai International Shipping Centre and reclamation project, the geomorphological evolution of the submerged delta will become more complex and thus deserves frequent monitoring in the future.

Keywords: erosion-accretion changes; spatio-temporal characteristics; causes; submerged delta; Yangtze (Changjiang) Estuary; China

\section{Introduction}

Over the past few decades, the delta response to the accelerating river damming and irrigation has been a topic of global concern because many deltas worldwide are retreating with the decline in river sediment discharge (Milliman et al., 1997; Trenhaile, 1997; Syvitski et al., 2009). Such studies have been undertaken on the Nile River (Fanos, 1995), the Danube River (Adrian, 2007), the Mississippi River (Blum and Roberts, 2009) and the Yellow River (Chen et al., 2005; Cui et al., 2011). Apart from the impact from upstream irrigation, the coastal submerging processes of the delta have been influenced by human activities in other ways. The large scale coastal engineering works have caused change in the nearshore sediment transport (Finkl, 1994; Anfuso, 2005).

As the area most directly affected by topographical evolution, the Yangtze Delta is sensitive to this decline in sediment load (Carriquiry et al., 2001; Frihy and Dewidar, 2003). A decreasing trend in deposition rate, and signs of retreat have already been seen in some areas (Yun, 2004; Yang et al., 2005) alongside the implementation of the South-to-North Water Diversion Project, the Three Gorges Reservoir of the Yangtze River, which is the world's largest hydropower project (Nilsson et al., 2005; Lu and Higgitt, 2011) and the effective development of eco-environmental construction and protection in the middle and upper reaches of the Yangtze River. The Deep-Water Channel Project and the large-scale reclamation project also became the major factors affecting the erosion-accretion evolution of the submerged delta (Dai et al., 2013; Wan, 2014).

In recent years, scholars have conducted research on the erosion-accretion evolution of the submerged delta in the Yangtze Estuary based on historic data. For instance, Li et al. (2007) preliminarily discussed the erosion-accretion response of the submerged delta to the sharp decline of the sediment load from the Yangtze River and the impoundment of the Three Gorges Reservoir, and analyzed the erosion-accretion pattern of the submerged delta in the Yangtze Estuary over the last decade. Ji et al. (2013) discussed the evolution of the nearshore coast in the Yangtze Estuary and the influencing factors of the last 30 years based on analysis of the status quo in tidal flats and nearshore areas, including the sediment and morphology from historical and observational data of the Yangtze Estuary. Kuang et al. (2013) predicted the morphological evolution process of the Yangtze Estuary for the next 20 years by considering tidal flow, suspended sediment transport and bed evolution based on the Delft3D-FLOW model, and discussed the impact of the Three Gorges Project on medium-term tidal flat evolution. These studies play an important role in the macro-understanding of the topographic changes, the evolutionary trend and causes of the submerged delta in the Yangtze River Estuary, but the problem with all these studies is that the analytical precision is unsatisfactory, and that erosion-accretion change characteristics in 
local areas, and the evolutionary trend and causes in recent years, need to be further studied.

Based on the topographic data measured with high precision in the past several years (1982, 1997, 2002 and 2010) provided by professional mapping departments, the erosion-accretion evolution and the spatio-temporal variation character of the submerged delta in the Yangtze Estuary and its causes, were systematically analyzed on the basis of the previous research and discussed in this paper. The study was divided into three periods: 1982-1997 (before the main river closure of the Three Gorges Project), 1997-2002 (between the main river closure and the impoundment of the Three Gorges Reservoir ${ }^{1}$ ), and 2002-2010 (after the impoundment of the Three Gorges Reservoir). Major research in this paper includes: (1) calculating the erosion-accretion quantity and rate of the submerged delta in three periods and eight areas, (2) comparatively analyzing the cross-sectional variation and the isobath change by laying 16 representative cross-sections in the four important sub-regions of the submerged delta, and (3) exploring the evolution mechanism and causes of the submerged delta in the four sub-regions according to sediment load quantity from the Datong Hydrological Station (the nearest-to-sea station, Datong Station for short), and the general situation of off-shore projects.

\section{Study area}

The Yangtze River (known as Changjiang in Chinese), originating from the Qinghai-Tibet Plateau at an elevation of $5100 \mathrm{~m}$ and extending $6380 \mathrm{~km}$ eastward to the East China Sea (Figure 1a), is the world's third largest river in terms of length and water runoff $\left(8940 \times 10^{8}\right.$ $\mathrm{m}^{3}$, from 1950 to 2012), and the fourth largest in terms of sediment load (Milliman and Farnsworth, 2011). The Yangtze Estuary is a moderate tidal estuary with multi-order bifurcations where the coastal runoffs and the tides abide by a law of opposition and supplementation with each other (Yun, 2004). Here, the river is divided first by Chongming Island into the North and South Branches, then the South Branch is split into the North and South Channels by Changxing and Hengsha Islands, and finally, the South Channel branches into the North Passage and South Passage by Jiuduansha Shoal (Figure 1b). According to records at Datong Station, the average annual sediment load from 1953 to 2012 greatly decreased after 1989 (from $4.71 \times 10^{8} \mathrm{t}$ in $1951-1989$ to $2.46 \times 10^{8} \mathrm{t}$ in $1990-2012$ ), and remains around $1.0 \times 10^{8}-1.5 \times 10^{8}$ t currently. Only $30 \%-50 \%$ of the sediment load is deposited in the submerged delta under the comprehensive effects of the coastal current driven by monsoons, tides and waves (Yang, 2003). Benefiting from this great sediment load, more than $1200 \mathrm{~km}^{2}$ of the coastal tidal flats are now distributed in the present river mouth, especially the forward area, widening the area of land by $17.5 \%$ in nearly six decades (Fan et al., 2013). The range of the tidal level varies greatly, and the maximum tidal range reaches $5.05 \mathrm{~m}$ according to the records of 14 stations within the river mouth. The wind direction is typically SSE-SE in summer and NW-NE in winter, which generates northward and southward longshore currents, respectively. Generally, the local wind waves are moderate, with a mean wave height of $1.0 \mathrm{~m}$ at the front of the estuary and $0.2 \mathrm{~m}$ at the upstream of the South Channel (Yang, 1999).

${ }^{1}$ Due to the lack of bathymetric data for 2003, this study uses data from 2002 for analysis. 
With a total area of $7465.14 \mathrm{~km}^{2}$, the study region ranges from $30^{\circ} 45^{\prime} 07^{\prime \prime} \mathrm{N}$ to $31^{\circ} 53^{\prime} 09^{\prime \prime} \mathrm{N}$ in latitude and $121^{\circ} 00^{\prime} 07^{\prime \prime} \mathrm{E}$ to $122^{\circ} 23^{\prime} 16^{\prime \prime} \mathrm{E}$ in longitude (Figure $1 \mathrm{~b}$ ). In order to analyze the spatial diversity of erosion-accretion evolution in the submerged delta, it is segmented into eight sub-regions according to the character of the three-order bifurcations and the $5 \mathrm{~m}$ isobath, which are: the North Branch of the Yangtze Estuary (NB) (Zone I ), the upper section of the South Branch of the Yangtze Estuary (SB) (Zone II), the North Channel of the Yangtze Estuary (NC) (Zone III), the South Channel of the Yangtze Estuary (SC) (Zone IV), the east tidal wetland of Chongming (CM) (Zone V), the east tidal wetland of Hengsha (HS) (Zone VI), the Jiuduansha wetland (JDS) (Zone VII), and the east tidal wetland of Nanhui (NH) (Zone VIII).The important region for analysis is marked with a red rectangle in Figure 1b. It includes four sub-regions (CM, HS, JDS and NH) from north to south (Figure 1c).
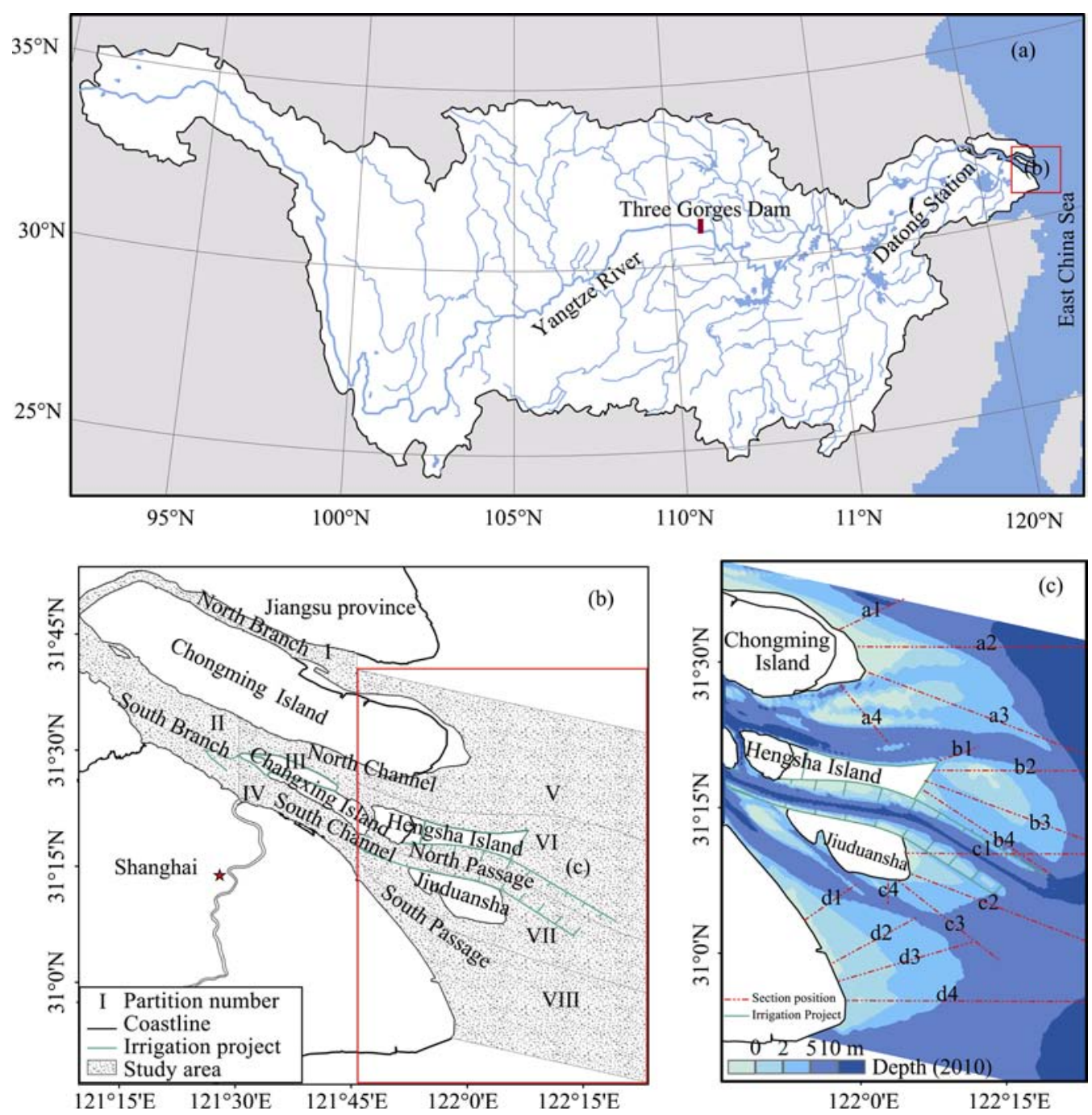

Figure 1 Yangtze River watershed, showing locations of the Three Gorges Dam (TGD) and Datong hydrological station (a); Map of the Yangtze Estuary and the eight study sub-regions (b); The distribution of the submerged delta and the 16 typical sections (c) described in this study 


\section{Material and methods}

Bathymetric data from1982 was extracted from Comprehensive Investigations Topographical Map of the Coastal Zone and Tidal Land Resources in 1982 (Chen, 1988), and 49000 points of measurement were included at a scale of 1:25,000. The bathymetric data for 1997, 2002, and 2010 were provided by the Water Resources Survey Bureau of the Yangtze Estuary, the Yangtze River Water Conservancy Commission, including 27,500, 42,000 and 118,700 points of measurement respectively at a scale of 1:50,000. All data were fit to the Mercator projection and 1954 Beijing Coordinate System with the benchmark of the theoretical lowest tidal level. Areas beyond the $5 \mathrm{~m}$ isobath of 1982 were excluded from this research due to a lack of bathymetric data. The records at Datong Station were obtained from the Yangtze River Water Resources Commission, including the mean runoff and the sediment load from 1950 to 2012.

The ordinary Kriging method was applied for spatial interpolation, and 3D Analyst and Spatial Analyst modules in ArcGIS10.0 were used to analyze the terrain data, concretely, including the erosion-accretion quantity and rate, the cross-sectional variation, the isobath change, and the mapping and output of the calculation results. The change curves of the 16 representative sections were drawn using Origin8.1. In this paper, the shoreline in 2010 is regarded as the land border to eliminate the effects of coastline evolvement when comparing analysis (the northeast of Chongming Island is bounded by the measured data because the area near the coastline has not been measured).

\section{Results}

\subsection{Analysis of erosion-accretion quantity and rate}

Topographical variations in the periods of 1982-1997, 1997-2002, 2002-2010 and 1982-2010 were analyzed based on the underwater topography digital elevation models (DEM) of 1982, 1997, 2002 and 2010. The erosion-accretion quantity and rates for the four periods were calculated (Table 1), and then the distribution figures for the erosion-accretion were drawn (Figure 2). The dry density was set as $1.4 \mathrm{t} / \mathrm{m}^{3}$ (Yun, 2004).

Table 1 Analysis of erosion-accretion for the different study periods

\begin{tabular}{lcccc}
\hline \multicolumn{1}{c}{ Indicators/periods } & $1982-2010$ & $1982-1997$ & $1997-2002$ & $2002-2010$ \\
\hline Area ratio of accretion and erosion zones & 0.92 & 0.90 & 1.14 & 1.05 \\
Net erosion-accretion quantity $\left(10^{8} \mathrm{~m}^{3} / \mathrm{yr}\right)$ & -0.54 & -1.26 & 0.74 & -0.01 \\
Net erosion-accretion rate $(\mathrm{cm} / \mathrm{yr})$ & -1.11 & -2.56 & 1.50 & -0.02 \\
Accretion area $\left(10^{8} \mathrm{~m}^{2}\right)$ & 23.66 & 23.32 & 26.21 & 25.18 \\
Accretion volume $\left(10^{8} \mathrm{~m}^{3}\right)$ & 41.98 & 31.02 & 28.01 & 30.96 \\
Erosion area $\left(10^{8} \mathrm{~m}^{2}\right)$ & 25.46 & 25.80 & 22.92 & 23.96 \\
Erosion volume $\left(10^{8} \mathrm{~m}^{3}\right)$ & 57.25 & 49.93 & 24.32 & 31.02 \\
\hline
\end{tabular}

Note: Negative values indicate erosion and positive values accretion.

In the period 1982-2010, the Yangtze Estuary mainly developed an erosion pattern. The erosion area accounted for $52.08 \%$ of the total area, with a net erosion-accretion quantity of $0.54 \times 10^{8} \mathrm{~m}^{3} / \mathrm{yr}$, which equals approximately $0.76 \times 10^{8} \mathrm{t}$ sediment being eroded each year 
(Table 1). Although it presented a balanced state of silting and scoring as a whole, the erosion-accretion changes in local regions are severe (Figure 2a).
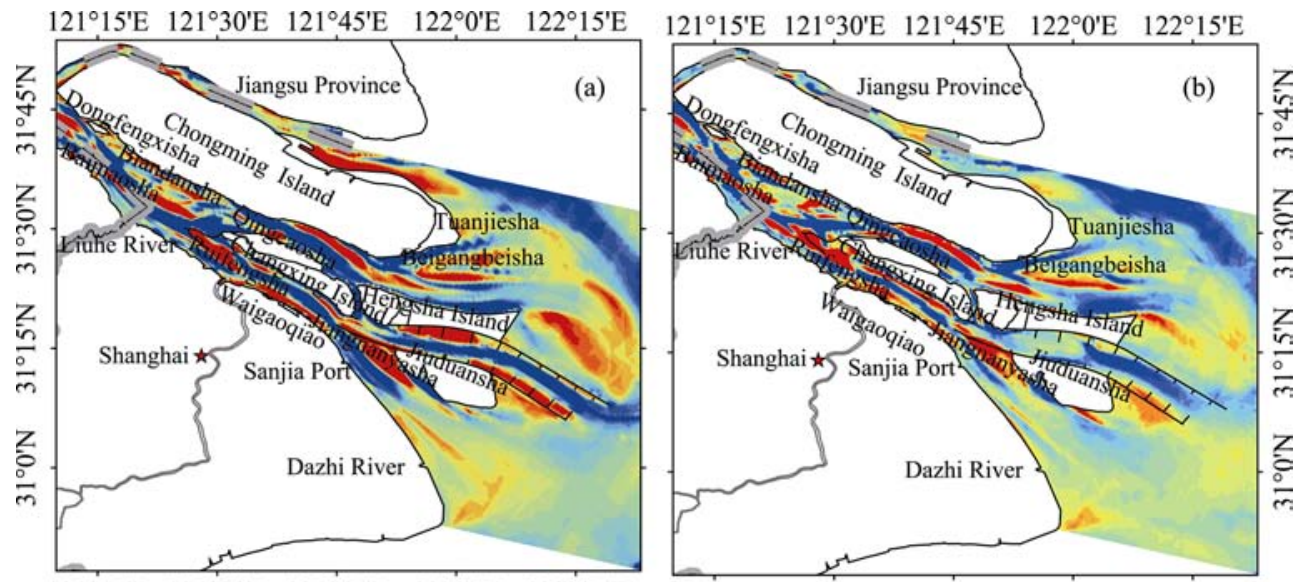

$121^{\circ} 15^{\prime} \mathrm{E} \quad 121^{\circ} 30^{\prime} \mathrm{E} \quad 121^{\circ} 45^{\prime} \mathrm{E} \quad 122^{\circ} 0^{\prime} \mathrm{E} \quad 122^{\circ} 15^{\prime} \mathrm{E}$
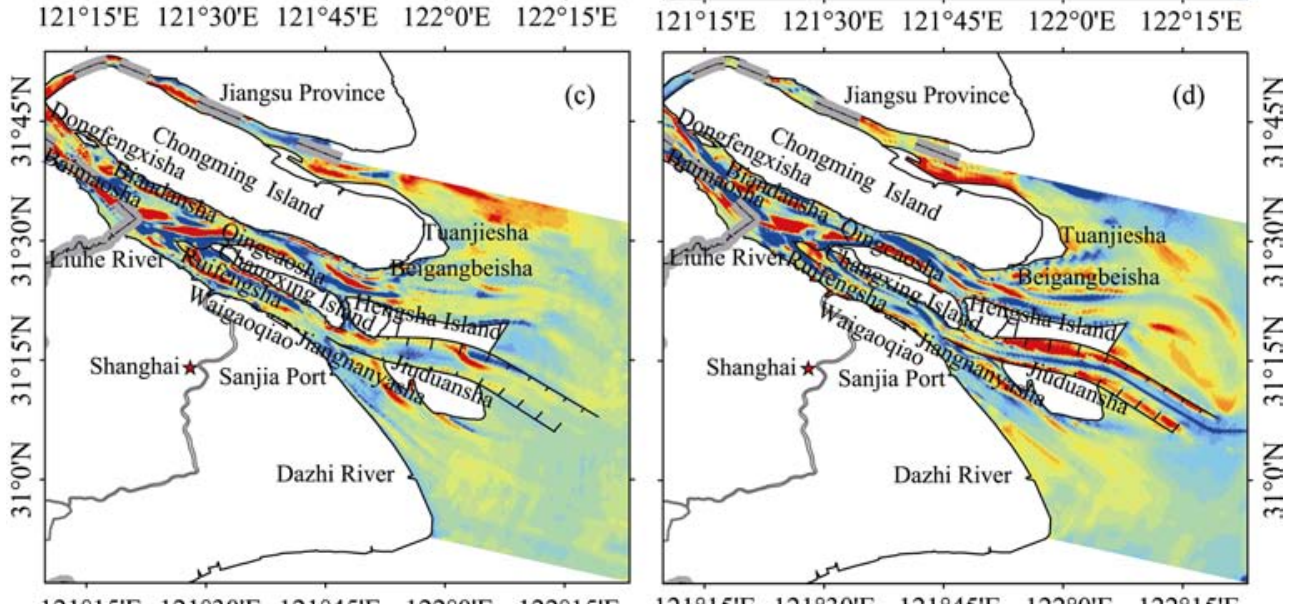

$121^{\circ} 15^{\prime} \mathrm{E} \quad 121^{\circ} 30^{\prime} \mathrm{E} \quad 121^{\circ} 45^{\prime} \mathrm{E} \quad 122^{\circ} 0^{\prime} \mathrm{E} \quad 122^{\circ} 15^{\prime} \mathrm{E}$

$121^{\circ} 15^{\prime} \mathrm{E} \quad 121^{\circ} 30^{\prime} \mathrm{E} \quad 121^{\circ} 45^{\prime} \mathrm{E} \quad 122^{\circ} 0^{\prime} \mathrm{E} \quad 122^{\circ} 15^{\prime} \mathrm{E}$

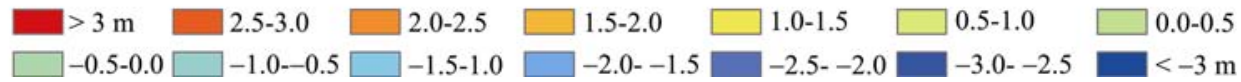

Figure 2 Accretion and erosion in the Yangtze Estuary during 1982-2010 (a), 1982-1997 (b), 1997-2002 (c), and 2002-2010 (d)

(Note: Negative values indicate erosion and positive values accretion. Elevation in meters.)

From 1982 to 1997, the evolution of the Yangtze Estuary was dominated by slight erosion. Accounting for $52.52 \%$ of the study area, the net erosion reached $1.26 \times 10^{8} \mathrm{~m}^{3}$, and the annual erosion depth was $2.56 \mathrm{~cm} / \mathrm{yr}$ (Table 1). The erosion areas were mainly located on the southern bank of SB, the northern bank of NC. The erosion in the northeast sea area of CM displayed a planar spatial distribution. The erosion of HS was mainly in the east of the chute with little change in the west; this may be because the topographical gradient and waves were stronger in the east (Figure 2b).

From 1997 to 2002, the evolution of the Yangtze Estuary was dominated by slight deposition. The accretion area $\left(26.21 \times 10^{8} \mathrm{~m}^{2}\right)$ was slightly greater than the erosion area $\left(22.92 \times 10^{8}\right.$ $\mathrm{m}^{2}$ ), and the net accretion quantity reached $0.74 \times 10^{8} \mathrm{~m}^{3}$, accounting for $6.91 \%$ of the Da- 
tong sediment discharge in the same period (Table 1). In addition the entry area of NB was seriously silted, and intensive sediment deposition was also found in areas around the shaped sand bodies at the center of SB, the mouth of NC, the northwest of HS, and along the dike of the Deep-Water Channel (Figure 2c).

From 2002 to 2010, the evolution of the Yangtze Estuary was dominated by erosion, covering $53.27 \%$ of the total area: the net erosion quantity and rate were $0.01 \times 10^{8} \mathrm{~m}^{3}$ and 0.02 $\mathrm{cm} / \mathrm{yr}$, respectively (Table 1 ). The erosion areas were mainly located on the southern bank of $\mathrm{SB}$, the northern bank of NC, and the Deep-Water Channel. The waterway of Beigangbeisha had also been seriously eroded. The erosion on the northern bank of NC arose from the construction of reclamation projects on Zhongyangsha and Qingcaosha, which made the main ebb currents move northward. As a result of the Deep-Water Channel Project, patterns of erosion and accretion in the North Channel and its nearby sea areas have changed greatly (Wang et al., 2008). The inlet section of NC and the vicinity of the groins silted up extensively (Figure 2d).

\subsection{Analysis of the spatio-temporal variation}

Analysis of the accretion and erosion area of the eight sub-regions in the four periods (Figure 1) showed that the character of the spatio-temporal variation of the erosion-accretion evolution in Yangtze Estuary was due to the influence of topography, the change of hydrodynamics and the engineering projects (Table 2).

Table 2 District statistics of erosion-accretion change in different periods in the Yangtze Estuary

\begin{tabular}{|c|c|c|c|c|c|c|c|c|}
\hline \multirow{2}{*}{$\begin{array}{l}\text { Indicators } \\
\text { Areas/periods }\end{array}$} & \multicolumn{4}{|c|}{ Net erosion-accretion quantity $\left(10^{8} \mathrm{~m}^{3}\right)$} & \multicolumn{4}{|c|}{ Net erosion-accretion rate $(\mathrm{cm} / \mathrm{yr})$} \\
\hline & $1982-2010$ & 1982-1997 & 1997-2002 & $2002-2010$ & 1982-2010 & 1982-1997 & 1997-2002 & 2002-2010 \\
\hline (1) $\mathrm{NB}$ & 1.91 & -0.76 & 1.35 & 1.32 & 3.11 & -2.32 & 12.31 & 7.52 \\
\hline (2) $\mathrm{SB}$ & -6.40 & -4.87 & 0.65 & -2.18 & -4.63 & -6.57 & 2.60 & -5.46 \\
\hline (3) $\mathrm{NC}$ & -4.70 & -2.99 & -0.76 & -0.94 & -10.57 & -12.57 & -9.41 & -7.27 \\
\hline (4) $\mathrm{SC}$ & -1.36 & 0.79 & -0.83 & -1.32 & -2.52 & 2.72 & -8.47 & -8.42 \\
\hline (5) $\mathrm{CM}$ & -4.53 & -11.28 & 5.85 & 0.89 & -1.31 & -6.07 & 9.45 & 0.90 \\
\hline (6) $\mathrm{HS}$ & -0.52 & -2.91 & -1.71 & 4.10 & -0.22 & -2.36 & -4.13 & 6.19 \\
\hline (7) JDS & -0.18 & 1.90 & -0.35 & -1.73 & -0.09 & 1.86 & -1.02 & -3.14 \\
\hline (8) $\mathrm{NH}$ & 0.83 & 1.41 & -0.56 & -0.02 & 0.27 & 0.86 & -1.03 & -0.03 \\
\hline
\end{tabular}

Note: Negative values indicate erosion, and positive values accretion.

According to the erosion-accretion variation of each sub-region shown in Table 2 and Figure 3, for the period 1982-2010, only NB and NH were silted up, at an annual rate of $3.11 \mathrm{~cm} / \mathrm{yr}$ and $0.27 \mathrm{~cm} / \mathrm{yr}$ respectively. The other sub-regions were eroded more or less, and the annual erosion rates from high to low were: NC $(10.57 \mathrm{~cm} / \mathrm{yr}), \mathrm{SB}(4.63 \mathrm{~cm} / \mathrm{yr})$, SC $(2.52 \mathrm{~cm} / \mathrm{yr})$ and CM $(1.31 \mathrm{~cm} / \mathrm{yr})$, while HS and JDS were in a relatively balanced state.

In the period 1982-1997, evolution in SC, JDS and NH was dominated by silting, and the accretion rate reached $2.72 \mathrm{~cm} / \mathrm{yr}, 1.86 \mathrm{~cm} / \mathrm{yr}$ and $0.86 \mathrm{~cm} / \mathrm{yr}$, respectively; the remaining five sub-regions were in an erosion state. The greatest annual erosion rate was in NC, and SB and CM remained in a serious state of erosion, with their annual erosion rate reaching $6.57 \mathrm{~cm} / \mathrm{yr}$ and $6.07 \mathrm{~cm} / \mathrm{yr}$, while the annual erosion rate of NB and HS was relatively small, 
at $2.32 \mathrm{~cm} / \mathrm{yr}$ and $2.36 \mathrm{~cm} / \mathrm{yr}$ respectively.

In the period 1997-2002, NB, SB and CM were in a state of deposition, and the rate of $\mathrm{NB}$ and $\mathrm{CM}$ reached $12.31 \mathrm{~cm} / \mathrm{yr}$ and $9.45 \mathrm{~cm} / \mathrm{yr}$, respectively, indicating that the North Branch of the Yangtze Estuary and the east tidal wetland of CM had been extensively silted. Other sub-regions were in an erosion state, it is especially obvious in NC and SC, for which the erosion rates were $9.41 \mathrm{~cm} / \mathrm{yr}$ and $8.47 \mathrm{~cm} / \mathrm{yr}$. This is mainly because more than $98 \%$ of the Yangtze River's water and sediment was discharged through the three outlets of the South Branch (Chen et al., 1985).

In the period 2002-2010, NB and CM remained in a state of deposition, but the deposition rate decreased, and was only $20.69 \%$ in the last period. Evolution in HS, disturbed by the construction of the Deep-Water Channel, turned from erosion to accretion, but that in SB changed from accretion to erosion with a high erosion rate of $5.46 \mathrm{~cm} / \mathrm{yr}$. The transformation was mainly due to the main stream direction of the upper section of the SB moving southward, and then the head of Baimaosha suffering from erosion which would lead to the sandy body moving down and narrowing. Finally, the south waterway erosion dramatically accelerated (Hu and Zhan, 2011). NC and SC remained in an intensified but stable state of erosion.

According to the comprehensive analysis, each sub-region had its notable spatio-temporal variation characteristics due to the difference in topography, hydro-dynamic conditions and manmade projects. The erosion-accretion change in the eight sub-regions was more complicated in different periods, except that erosion in NC remained constant from 1982 to 2010. Focusing on the two periods of 1997-2002 and 2002-2010, evolution in NB and CM involved deposition, which was contrary to the situation in NC, SC, JDS and NH. Evolution in SB also turned from erosion in 1997-2002 to accretion in 2002-2010, and that in HS was the opposite.

\subsection{Analysis of erosion-accretion change in typical sections}

In order to make an in-depth analysis of the change in topography of the submerged delta, 16 sections were divided into four important sub-regions (CM, HS, JDS and NH) in the Yangtze Estuary (Figure 1c). From north to south, respectively: the east tidal wetland of Chongming (a1, a2, a3, a4), Hengsha (b1, b2, b3, b4), Jiuduansha (c1, c2, c3, c4) and Nanhui (d1, d2, d3, d4). Sections a2, b1, c1 and d3 stretch in an easterly direction among them.

(1) The eastern tidal wetland of Chongming

A conclusion can be drawn that, according to cross-section variation of the Chongming east wetland, the submerged delta of CM has moved toward the sea on the whole, since Sections a1, a2 and a3 moved about 8-12 km away from the coastline, while Section a4 was mostly dominated by erosion, and the deposition depth reached $15.96 \mathrm{~cm}$ (Figure 3). It was found that, at Section a1, the offshore areas were in a deposition state, while conversion of erosion and accretion occurred at $-4 \mathrm{~m}$ isobaths. The areas deeper than $-1 \mathrm{~m}$ isobath at Section a2 were extensively eroded (Figure 3). At Section a3, a gully developed in the coastal areas, and the areas beyond the $-10 \mathrm{~m}$ isobath were also in an erosion state, while the areas between them were silting. The erosion-accretion evolution of Section a 4 was very complex and variable and the turning point from accretion to erosion was at $-5 \mathrm{~m}$ isobath. Between Chongming Island and Beigangbeisha, an ever-deepening, broadening gully was formed 
because of the variation in hydrodynamic characteristics.

On the basis of the analysis above, it was concluded that evolution of the submerged delta at $\mathrm{CM}$ was dominated by accretion within $-5 \mathrm{~m}$ isobaths, while erosion was between $-5 \mathrm{~m}$ and $-10 \mathrm{~m}$ isobaths, except for the gully which had constantly eroded since it was formed.
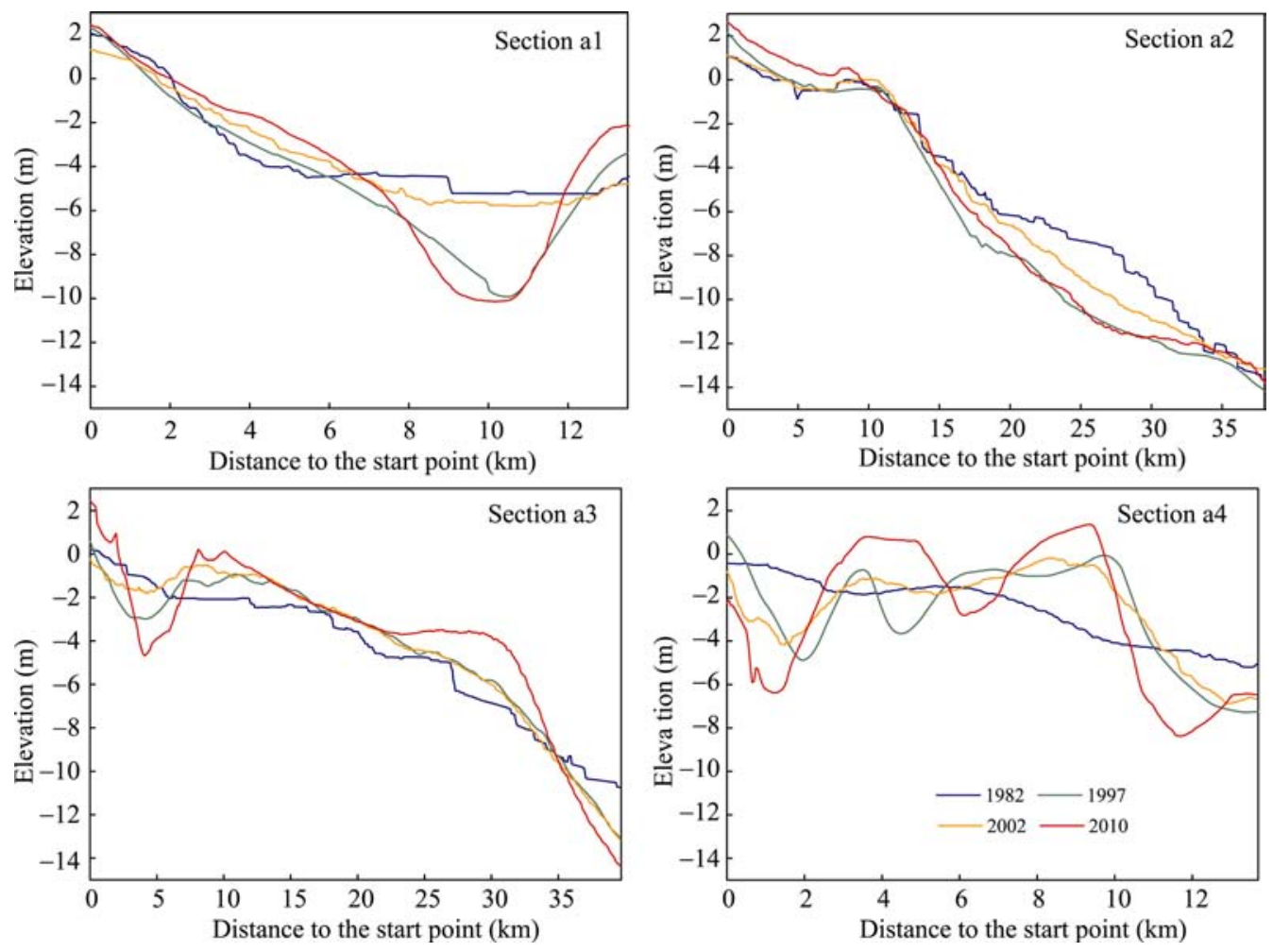

Figure 3 Cross-section variation for Chongming eastern wetland (CM)

(2) The Hengsha shoal

Variation in the cross-section at the Hengsha Shoal showed that evolution here was dominated by accretion, excluding the coastal areas at Section b1 (Figure 4). The annual sediment thickness reached $0.97 \mathrm{~m}$ and $3.03 \mathrm{~m}$ along Sections b2 and b3 during the period from 1982 to 1997, while the annual erosion thickness along Sections b1 and b4 was $1.23 \mathrm{~m}$ and $0.63 \mathrm{~m}$. Section b1 was located in NC and deposition began in 1997, when the flood in 1998 generated over 63,300 $\mathrm{m}^{3} / \mathrm{s}$ peak flow in one month in Yichang Station and thereby pushed the sand ridges to move down (Hayashi et al., 2008). The evolution at Sections b2 and b3 was relatively stable during 1997-2002, the areas within $5 \mathrm{~m}$ isobaths were lightly eroded resulting from the scouring effects of the water and sediment from upstream and storm surge (Yu et al., 2013). In the period 1997-2002, the erosion-accretion equilibrium point of the three sections from north to south were $-5.5 \mathrm{~m},-3 \mathrm{~m}$ and $-3 \mathrm{~m}$, respectively, and evolution at Section b3, which stretched directly east, was the least stable. At Sections b2 and b3, the evolution trends were relatively convex during 2002-2010, with erosion within a $5 \mathrm{~km}$ offshore sea, beyond which it was in a deposition state. In the same period, erosion was widely distributed at Section b4, and the topography of 2010 changed in a hackly pattern for the construction of the Deep-Water Channel and the north dike. 

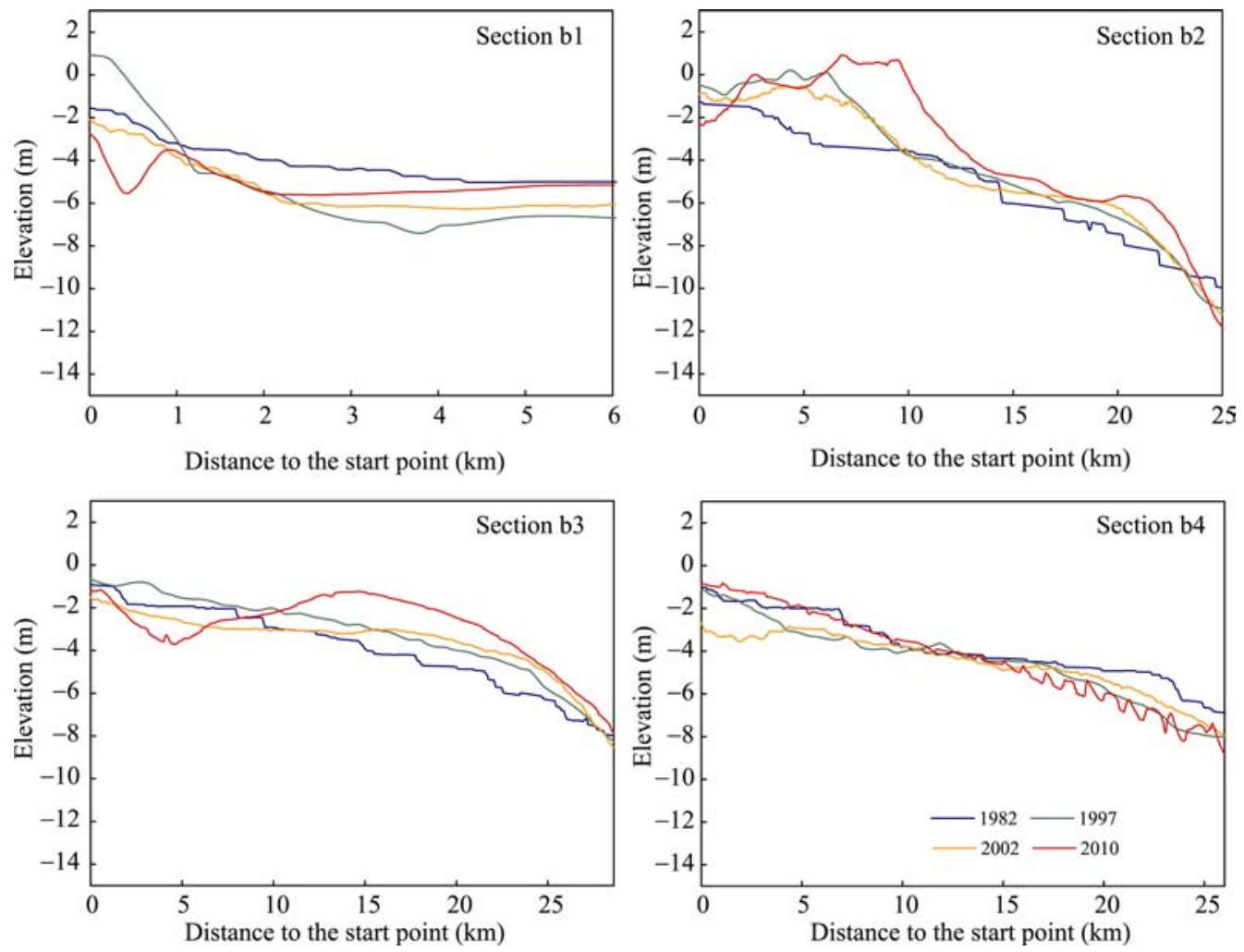

Figure 4 Cross-section variation for Hengsha shoal (HS)

(3) The Jiuduansha wetland

According to the cross-section variation of the Jiuduansha wetland, evolution along Sections c2 and c3 was relatively stable, which was thought to be a natural change (Figure 5). Section c1 through the lower section of the North Passage presented a smooth curve because of the wide-shallow channel pattern. The constant erosion after 1997 was mainly due to the realization of the targets in constructing the Deep-Water Project, which aimed to achieve a maximum navigation depth of 8.5 m, $10.0 \mathrm{~m}$ and $12.5 \mathrm{~m}$ in turn. During 1982-2010, evolution in the eastern and southern areas along Jiuduansha was dominated by constant erosion, and the erosion thickness was $0.86 \mathrm{~m}$ and $0.24 \mathrm{~m}$ respectively at Sections c2 and c3. A slight erosion appeared in the southeastern Section c3 in the period from1982 to 2010, mainly due to the effect of the ratio of water and sediment diversion, which reached 68\% in 1964-1983 and then gradually decreased and remained at approximately 50\% after 1983 (Yun, 1983). The erosion-accretion equilibrium point of Section c 4 was approximately $-5 \mathrm{~m}$, and there was a notable conversion in sediment change due to the flood in 1998, the Deep-Water Channel Project and the silt-promoting project in NH (Xie et al., 1999; Yang et al., 2011).

(4) The eastern tidal wetland of Nanhui

Accretion in varying degrees has appeared in the three sections of the Nanhui eastern wetland. Accretion within $5 \mathrm{~m}$ isobath was constant and steadily intensified over the years, especially along Sections $\mathrm{d} 1$ and $\mathrm{d} 2$ (Figure 6). The erosion-accretion equilibrium point of Section $\mathrm{d} 1$ was approximately $-4 \mathrm{~m}$, and the deposition rate $(0.13 \mathrm{~m} / \mathrm{yr})$ during the period 

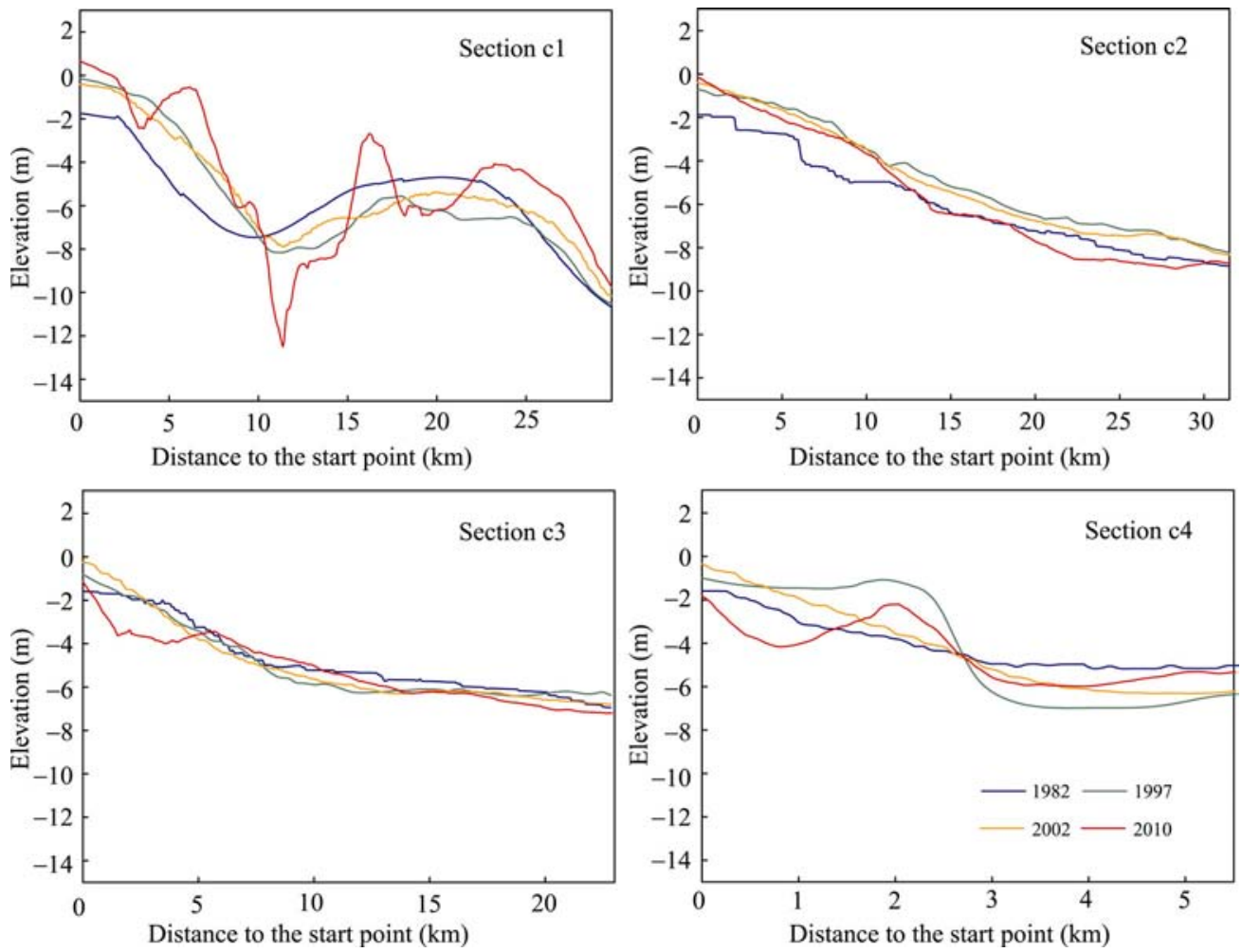

Figure 5 Cross-section variation for Jiuduansha wetland (JDS)
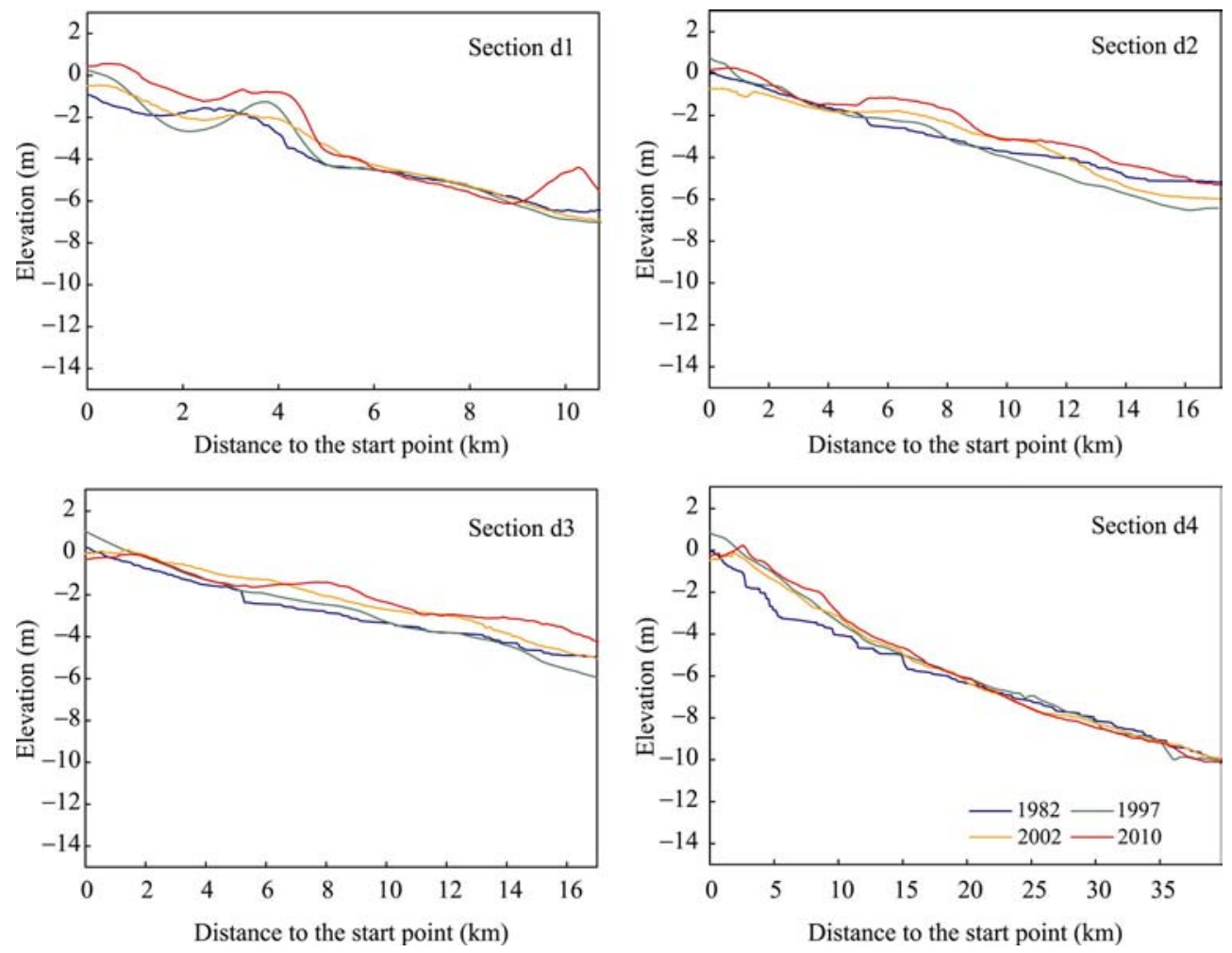

Figure 6 Cross-sectional variation of the Nanhui eastern wetland (NH) 
2002-2010 was higher compared with the period 1997-2002. Erosion arose in the area beyond the $-2 \mathrm{~m}$ isobath along Section d2 from 1997 to 2002, and Section d2 was dominated by it throughout the whole period. Evolution at Section d3 was relatively stable and not obviously changed from an overall perspective, which was mainly developed as erosion, the erosion-accretion equilibrium point was $-6 \mathrm{~m}$, and the annual deposition thickness was only $0.03 \mathrm{~m}$. The highest average elevation $(1.53 \mathrm{~m})$ within the $10 \mathrm{~km}$ offshore sea was distributed at Section d4, compared with the other three sections.

\section{Discussion}

\subsection{The spatio-temporal characteristics of the isobaths in the four main sub-regions}

The average sediment load from Datong Station during the period 1982-1997 was $3.78 \times 10^{8} \mathrm{t} / \mathrm{yr}$, and was further reduced to $3.00 \times 10^{8} \mathrm{t} / \mathrm{yr}$ in $1997-2002$ and $1.59 \times 10^{8}$ $\mathrm{t} / \mathrm{yr}$ in 2002-2010 (Figure 7). According to previous research results, a shortage of deposit supply due to the sharp decline in the sediment load led directly to the slowdown of deposition and even a reversal of the submerged delta (Yun, 2004; Yang et al., 2005).

To explore the variation characteristics of the submerged delta in the Yangtze Estuary, the annual variation of the ESA,

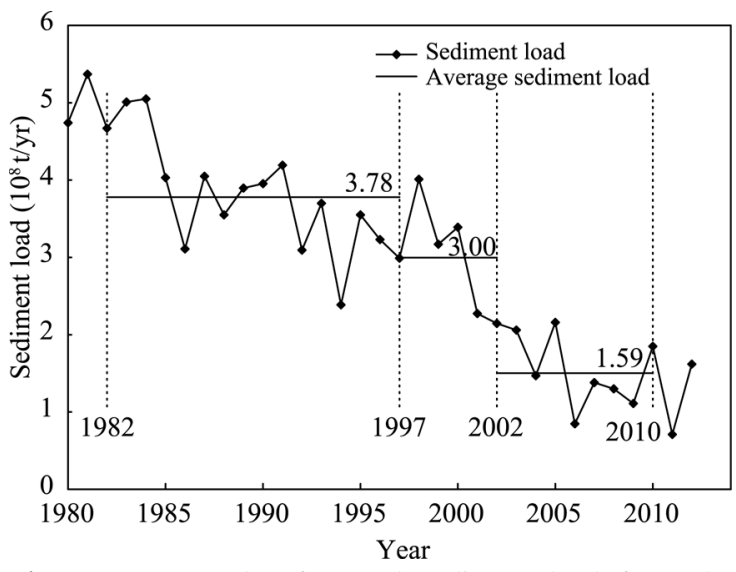

Figure 7 Records of annual sediment load from the Yangtze River at Datong (the farthest downstream station) during 1980-2012 of $2 \mathrm{~m}, 5 \mathrm{~m}, 10 \mathrm{~m}$ and $15 \mathrm{~m}$ isobaths in the four sub-regions (CM, HS, JDS and NH) were calculated (Figures 8 and 9) and compared with the those of the sediment load at Datong Station (Figure 7).

(1) The annual change in the ESA of the $2 \mathrm{~m}$ isobath

The movement of the $2 \mathrm{~m}$ isobath was due to the complex local hydrodynamic and geomorphologic conditions, as well as the sediment loads. The $2 \mathrm{~m}$ isobath advanced in some areas and retreated in others (Figures 8 and 9). The annual change in the ESA of $2 \mathrm{~m}$ isobath showed an inverted V-shaped trend in both $\mathrm{CM}$ and $\mathrm{NH}$, which declined from $7.48 \mathrm{~km}^{2} / \mathrm{yr}$ and $4.73 \mathrm{~km}^{2} / \mathrm{yr}$ in the period $1997-2002$ to $0.93 \mathrm{~km}^{2} / \mathrm{yr}$ and $0.59 \mathrm{~km}^{2} / \mathrm{yr}$ in the period 2002-2010, and the declining rates were $12.43 \%$ and $12.47 \%$, respectively. However, the change in HS and JDS presented a V-shaped trend, and the ESA of $2 \mathrm{~m}$ isobath continued to decrease during 1997-2002 at a speed of $9.46 \mathrm{~km}^{2} / \mathrm{yr}$ and $2.35 \mathrm{~km}^{2} / \mathrm{yr}$, respectively, while rapidly increasing during 2002-2010 at a speed of $13.12 \mathrm{~km}^{2} / \mathrm{yr}$ and $4.18 \mathrm{~km}^{2} / \mathrm{yr}$, respectively, as a result of the sediment-blocking effect of the double guide jetties of the Deep-Water Project (Figure 9).

(2) The annual change in the ESA of the $5 \mathrm{~m}$ isobath

The ESA of the $5 \mathrm{~m}$ isobath continued to expand in both CM, JDS and NH, but the annual change in these three sub-regions showed an inverted V-shaped trend, which was a decline 
from $4.14 \mathrm{~km}^{2} / \mathrm{yr}, 3.37 \mathrm{~km}^{2} / \mathrm{yr}$ and $3.66 \mathrm{~km}^{2} / \mathrm{yr}$ in the period 19972002 to $2.66 \mathrm{~km}^{2} / \mathrm{yr}, 1.71 \mathrm{~km}^{2} / \mathrm{yr}$ and $2.78 \mathrm{~km}^{2} / \mathrm{yr}$ in the period 2002-2010, respectively. This suggested a positive relationship between the growth rate (Figure 9) and the sediment load (Figure 7), which also fell from $2.99 \times 10^{8} \mathrm{t} / \mathrm{yr}$ in 1997-2002 to $1.50 \times 10^{8} \mathrm{t} / \mathrm{yr}$ in 2002-2010, as measured at Datong Station. However, the overall relationship between growth rate and riverine sediment load was unclear in HS: it presented a V-shaped trend in the ESA of the $5 \mathrm{~m}$ isobath, and declined from $4.88 \mathrm{~km}^{2} / \mathrm{yr}$ in 1997-2002 to $7.73 \mathrm{~km}^{2} / \mathrm{yr}$ in 20022010 (Figure 9).

(3) The annual change in the ESA of the $10 \mathrm{~m}$ isobath

As shown in Figure 9, the ESA of the $10 \mathrm{~m}$ isobath in the four main

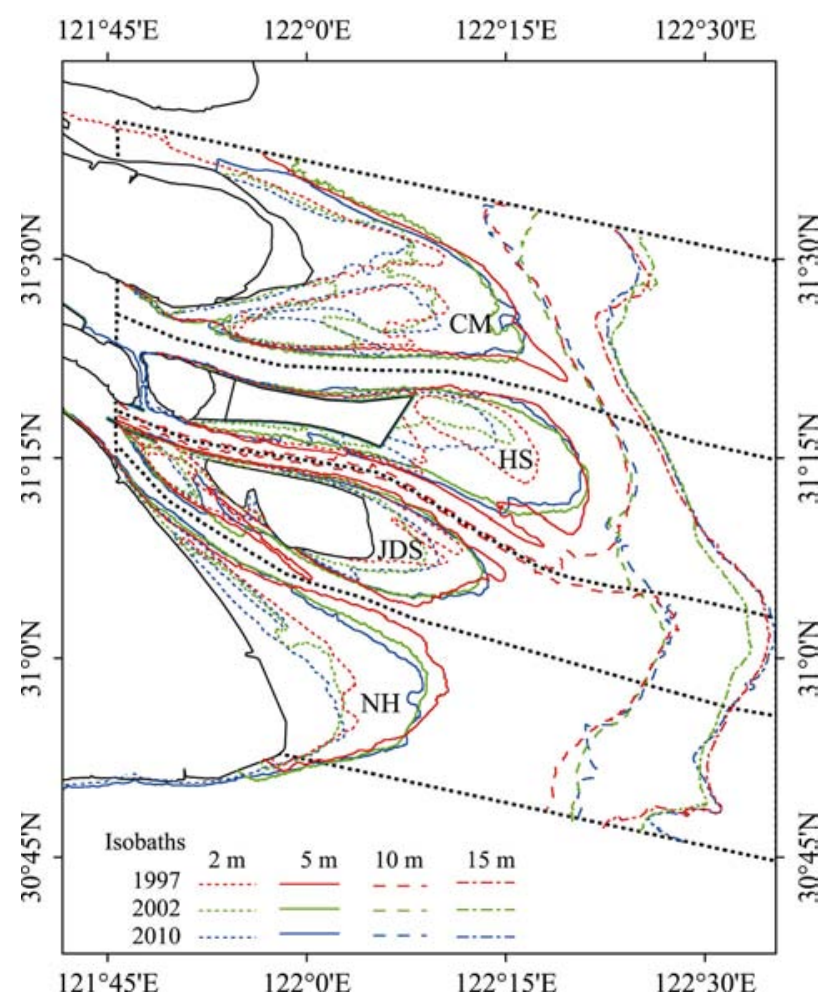

Figure 8 Zoning sketch of isobaths and the four important regions in the submerged delta

sub-regions significantly decreased from 2002 to 2010, compared with that in the period 1997-2002, and in CM, HS, and JDS the annual trend of change in the ESA of the $10 \mathrm{~m}$ isobath is consistent, all decreasing from $-1.37 \mathrm{~km}^{2} / \mathrm{yr},-1.27 \mathrm{~km}^{2} / \mathrm{yr}$, and $-1.69 \mathrm{~km}^{2} / \mathrm{yr}$ in 1997-2002 to $-6.26 \mathrm{~km}^{2} / \mathrm{yr},-7.90 \mathrm{~km}^{2} / \mathrm{yr}$, and $-4.70 \mathrm{~km}^{2} / \mathrm{yr}$ during 2002-2010, respectively

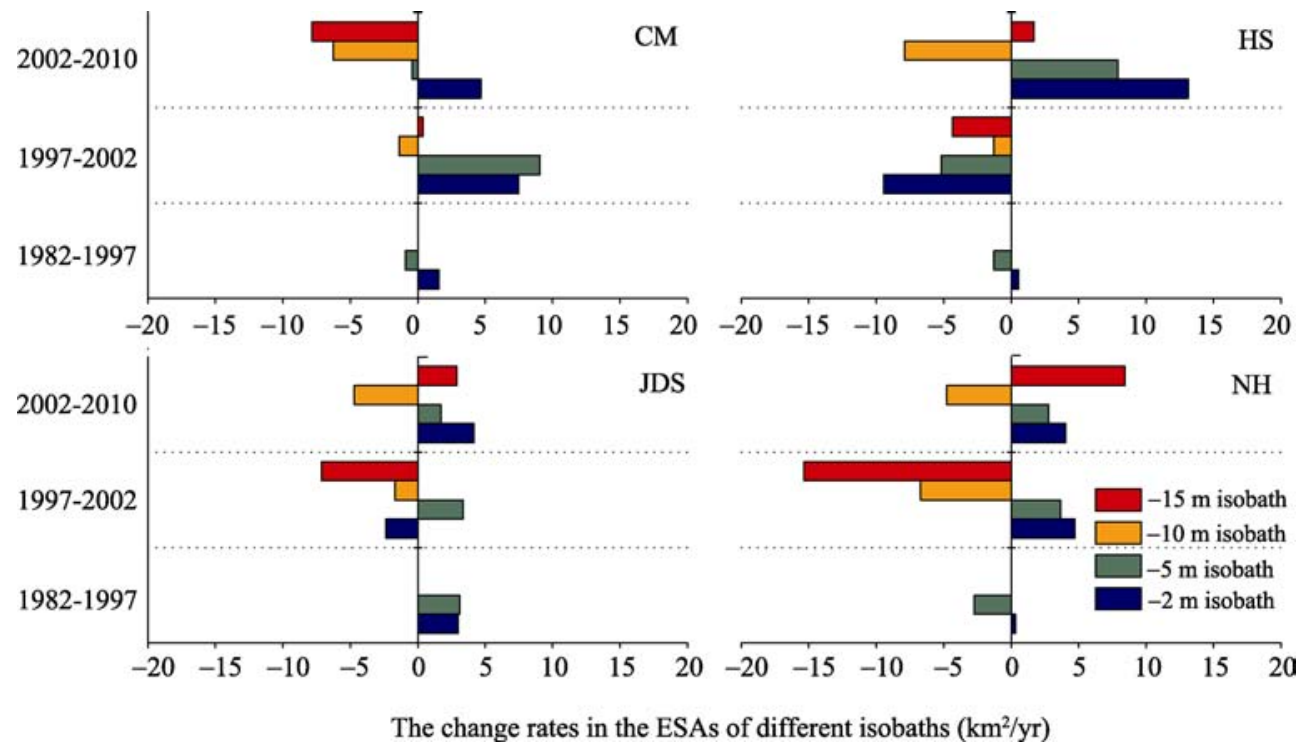

Figure 9 The change rates in the ESAs of different isobaths in different periods 
(Figure 9). It also suggested a positive relationship between the growth rate (Figure 9) and the sediment load (Figure 7). However, the rate of change in CM had decreased from -6.71 $\mathrm{km}^{2} / \mathrm{yr}$ in $1997-2002$ to $-4.78 \mathrm{~km}^{2} / \mathrm{yr}$ in $2002-2010$.

(4) The annual change in the ESA of the $15 \mathrm{~m}$ isobath

As shown in Figure 8, the $15 \mathrm{~m}$ isobath in CM advanced during 1997-2002 and retreated during 2002-2010 (Figure 8), and the annual rate of change in the ESA decreased from 0.39 $\mathrm{km}^{2} / \mathrm{yr}$ in 1997-2002 to $-7.83 \mathrm{~km}^{2} / \mathrm{yr}$ in 2002-2010 (Figure 9), which is in accordance with the decrease in the sediment load from upstream. This was the opposite in HS, JDS and NH, however, where the change rate increased from $-4.35 \mathrm{~km}^{2} / \mathrm{yr},-7.13 \mathrm{~km}^{2} / \mathrm{yr}$, and -15.37 $\mathrm{km}^{2} / \mathrm{yr}$ during 1997-2002 to $1.68 \mathrm{~km}^{2} / \mathrm{yr}, 2.91 \mathrm{~km}^{2} / \mathrm{yr}$, and $8.43 \mathrm{~km}^{2} / \mathrm{yr}$ during 2002-2010, respectively (Figure 9).

In summary, the changes in the ESA of the $2 \mathrm{~m}, 5 \mathrm{~m}, 10 \mathrm{~m}$ and $15 \mathrm{~m}$ isobaths were complex in the three periods. The ESA of the $2 \mathrm{~m}$ and $5 \mathrm{~m}$ isobaths in the four sub-regions continued to increase. Specifically, the ESA of the $2 \mathrm{~m}$ isobath in HS and JDS increased, while that in CM and NH decreased during 1997-2010. The ESA of the $5 \mathrm{~m}$ isobath in HS continued to increase, perhaps as a response to the construction of the Deep-Water Channel; in contrast, it experienced a deceleration in growth in CM, JDS and NH. The ESA of the $10 \mathrm{~m}$ isobath showed no significant change, and erosion appeared in some parts of the areas (Figure 8). The $15 \mathrm{~m}$ isobath changed slightly during 1997-2010 in CM, and those in the other three sub-regions continued expanding outward at a slow speed. The change rate of the four main sub-regions were different from each other in the last 30 years, but generally, the $2 \mathrm{~m}$ and $5 \mathrm{~m}$ isobaths advanced while the $10 \mathrm{~m}$ and $15 \mathrm{~m}$ isobaths retreated.

Correlation analysis was used to study the relationship between the decline of the ESA and the sediment load. The change in the ESA of the $2 \mathrm{~m}, 5 \mathrm{~m}, 10 \mathrm{~m}$ and $15 \mathrm{~m}$ isobaths in $\mathrm{CM}$ was consistent with the sediment load at Datong, and in NH and JDS, the ESA of the 2 $\mathrm{m}, 5 \mathrm{~m}$ and $10 \mathrm{~m}$ isobaths changed in a similar way, but that of the $15 \mathrm{~m}$ isobath changed contrarily. The ESA of the $10 \mathrm{~m}$ isobath in HS also changed accordingly with the sediment supply, while it was opposite for the $2 \mathrm{~m}, 5 \mathrm{~m}$ and $15 \mathrm{~m}$ isobaths. In the four important sub-regions, therefore, only the ESA of isobaths in CM can be used to build a relationship with the sediment load, indicating that CM was the area that responded to the decrease in the sediment load at Datong. There was also a relationship between the ESA of the $10 \mathrm{~m}$ isobaths and the sediment load from upstream in the whole study.

\subsection{The erosion-accretion tendency of the submerged delta in the Yangtze Estuary}

In order to fully study the erosion-accretion tendency of the submerged delta in the Yangtze Estuary, the ESAs of the 2 m, 5 m, 10 m and 15 m isobaths in 1982, 1997, 2002 and 2010 were analyzed and compared (the area is shown in Figure 1c) (Table 3).

As revealed in Table 3, the ESA of the $2 \mathrm{~m}, 5 \mathrm{~m}$ and $15 \mathrm{~m}$ isobaths continued to increase on the whole, and that of the $15 \mathrm{~m}$ isobath increased the least, however, the ESA of the $10 \mathrm{~m}$ isobath decreased slightly during 2002-2010. In consideration of the missing data for the area beyond $5 \mathrm{~m}$ isobaths in 1982, the changes in the ESA of the isobaths was closely analyzed, focusing on the period 1997-2010.

During 1997-2002, the average annual change rate of the ESA of the $2 \mathrm{~m}, 5 \mathrm{~m}, 10 \mathrm{~m}$ and $15 \mathrm{~m}$ isobaths were, in order, $0.39 \mathrm{~km}^{2} / \mathrm{yr}, 6.29 \mathrm{~km}^{2} / \mathrm{yr}, 3.74 \mathrm{~km}^{2} / \mathrm{yr}$ and $-8.92 \mathrm{~km}^{2} / \mathrm{yr}$ respectively, and during 2002-2010, were $26.03 \mathrm{~km}^{2} / \mathrm{yr}, 14.88 \mathrm{~km}^{2} / \mathrm{yr},-22.40 \mathrm{~km}^{2} / \mathrm{yr}$ and 1.04 
Table 3 Statistics for the ESA of different isobaths

\begin{tabular}{|c|c|c|c|c|c|c|c|}
\hline \multirow{2}{*}{ Year } & \multicolumn{4}{|c|}{ Total area $\left(\mathrm{km}^{2}\right)$} & \multicolumn{3}{|c|}{ Change rate $\left(\mathrm{km}^{2} / \mathrm{yr}\right)$} \\
\hline & 1982 & 1997 & 2002 & 2010 & 1982-1997 & 1997-2002 & 2002-2010 \\
\hline $\begin{array}{l}\text { The area within } \\
2 \mathrm{~m} \text { isobath }\end{array}$ & 526.29 & 607.93 & 609.88 & 818.12 & 5.44 & 0.39 & 26.03 \\
\hline $\begin{array}{l}\text { The area within } \\
5 \mathrm{~m} \text { isobath }\end{array}$ & 1685.09 & 1657.73 & 1712.27 & 1808.22 & -1.82 & 10.91 & 11.99 \\
\hline $\begin{array}{l}\text { The area within } \\
10 \mathrm{~m} \text { isobath }\end{array}$ & l & 3938.22 & 3883.00 & 3693.94 & l & -11.04 & -23.63 \\
\hline $\begin{array}{l}\text { The area within } \\
15 \mathrm{~m} \text { isobath }\end{array}$ & l & 4856.77 & 4724.45 & 4765.91 & / & -26.46 & 5.18 \\
\hline
\end{tabular}

$\mathrm{km}^{2} / \mathrm{yr}$, respectively. The $2 \mathrm{~m}$ isobaths in all four main sub-regions suggested a trend of eastward shift, probably due to the sediment load from upstream and the effect of the estuarine engineering. The change rate of the ESA of the $5 \mathrm{~m}$ isobaths in the whole area increased at a slower rate of $10.91 \mathrm{~km}^{2} / \mathrm{yr}$ during 1997-2002 and $11.99 \mathrm{~km}^{2} / \mathrm{yr}$ during 2002-2010 (Table 3), which indicated that the ESA of the $5 \mathrm{~m}$ isobath was in a state of continuous expansion during 1997-2010, and the rate increased dramatically. The ESA of the $10 \mathrm{~m}$ isobath decreased from $3938.22 \mathrm{~km}^{2}$ in 1997 to $3693.94 \mathrm{~km}^{2}$ in 2010 , the $10 \mathrm{~m}$ isobath transformed from expanding outward (2002-2010) to receding inward (1997-2002), and the change rate was higher than other isobaths. As shown in Figure 9, the major cause of the shift of the 10 $\mathrm{m}$ isobath was the construction of the Deep-Water Channel in the North Passage. The $15 \mathrm{~m}$ isobath receded and expanded successively, and generally the ESA decreased slightly from $4856.77 \mathrm{~km}^{2}$ in 1997 to $4765.91 \mathrm{~km}^{2}$ in 2010 . Since almost all the riverine sediment load to the coastal ocean was transported via these three outlets, this slow decline of the ESA of 15 $\mathrm{m}$ isobath can partly account for the impact from the Three Georges Dam on the Yangtze River sediment load and the submerged delta in the estuary.

In summary, on the premise that the annual sediment load reached up to $3.02 \times 10^{8} \mathrm{t} / \mathrm{yr}$ during 1982-2010, the ESA of the $2 \mathrm{~m}, 5 \mathrm{~m}$ and $15 \mathrm{~m}$ isobaths increased in the three periods, but that of the $10 \mathrm{~m}$ isobath showed an obvious decreasing trend. It can therefore be judged that the area within $15 \mathrm{~m}$ isobath, especially that within $2 \mathrm{~m}, 5 \mathrm{~m}$ and $10 \mathrm{~m}$ in the submerged delta, was greatly influenced by human activities in the last 30 years, such as the Deep-Water Channel and the large-scale reclamation project in the Yangtze Estuary

\subsection{Causes of the erosion-accretion change in the submerged delta}

In recent years, more and more attention has been paid to the causes of the erosion-accretion changes in the submerged delta. It has been found that, under natural conditions, there was an obvious positive correlation between the annual sediment load and the erosion-accretion evolution. In past decades, however, this relationship in the Yangtze Estuary has been disturbed by human activities to a great extent, such as for reclamation, dredging and shore protection. As a result, some areas showed a strong trend of accretion.

In the study area, this includes: (1) the NB of the Yangtze Estuary, where the accretion rate reached up to $8.11 \mathrm{~cm} / \mathrm{yr}$ between 1997 and 2010, since the water-sediment condition was changed by the reclamation engineering in the Xuliujing reach of the Yangtze River and the Dongfengxisha; (2) the diverging area between NC and SC, where the evolution did not follow the natural trend, but the erosion was under control for the construction of the Xinliuhesha guarding beach and submerged dike in the channel of Nansha Head in 2007; (3) the 
the entrance section of NC, where the maximum vertical accretion rate reached $7.87 \mathrm{~m} / \mathrm{yr}$, as a consequence of a water-resisting effect from the spur-dikes in the Deep-Water Channel which caused significant decrease in runoff and sediment load; because of the eddy flow effect, there was also a trend of accretion at the sand bar in the mid-course of NC and the spur-dike field; (4) the north margin of Jiuduansha, where the accretion was distributed along the south dike and expanded northwestward; the $5 \mathrm{~m}$ isobath also moved northward due to being disturbed by the construction of the Deep-Water Channel, which would have weakened the water-sediment exchange and blocked the tide currents; (5) the east tidal wetland of Hengsha, where the erosion-accretion evolution changed dramatically due to the construction of the north dikes; because of the constantly accretion in the east of Baitiaozisha, the north-south channeling ditch presented a warped and contracted pattern, and then developed into an east-west sand body along the north dike. In addition, the deposition rate has grown significantly in the area within the $2 \mathrm{~m}$ and $5 \mathrm{~m}$ isobaths enlarging by 104.96 $\mathrm{km}^{2}$ and $61.8 \mathrm{~km}^{2}$ respectively during 2002-2010; (6) the $2 \mathrm{~m}$ and $5 \mathrm{~m}$ isobaths of $\mathrm{NH}$ clearly expanded outward due to implementation of the Donghai Bridge and the large-scale reclamation projects. As there is no large engineering project located in CM, the erosion-accretion evolution maintained a natural pattern, which may reflect the potential effect of a reduction in the sediment load in recent years. The evolution in HS, JDS and NH was very complicated, however, because of the influence of the Deep-Water Project, the reclamation project, the Donghai Bridge and other projects.

With the Xiluodu hydropower station (the third largest hydropower station in the world, located in the lower reach of Jinsha River) beginning filling in 2013, and the water level in the Three Gorges Reservoir rising up to $175 \mathrm{~m}$ in 2010, the sediment concentration of the runoff has reduced. The South-to-North Water Diversion Project is being gradually implemented, as protection of the ecological environment in the Yangtze Basin has gained more attention than ever before, and so the sediment load will continue to decrease for a long time. In order to earnestly implement the requirements of "Building the International Shipping Center by 2020"in the "Shanghai Master Plan (1999-2020)", and to follow the trend for maximization of container ships and relieve the pressure on Shanghai port, "the new land use plan" in the Hengsha shoal, which was planned as a second "Pudong” (Bao et al., 2013) and "the excavated-in harbor and its artificial islands" (Ding et al., 2013) were proposed by some scholars. If these projects are carried out, it will inevitably impact the erosion-accretion state of the harbor and its channels, and the sedimentary hydrodynamic field in the North Channel, the North Passage and the South Passage. Consequently, the natural evolution of the submerged delta will be further influenced by these artificial projects and become more complicated, and thus more attention should be paid to this area.

\section{Conclusions}

(1) In the past 30 years, the evolution of the study area was dominated by slight erosion, which accounted for $51.83 \%$ of the whole area, and it experienced a shift of "erosion-accretion-erosion again”. There was also an obvious spatio-temporal difference in erosion-accretion evolution between the eight sub-regions, and only NC was in a state of erosion throughout. Focusing on the two periods of 1997-2002 and 2002-2010, deposition was dominant in NB and CM and erosion was dominant in NC, SC, JDS and NH. Evolution in 
SB changed from erosion in 1997-2002 to accretion in 2002-2010, which was the opposite of that in HS.

(2) The erosion-accretion characteristics of the four important sub-regions of the submerged delta in the Yangtze Estuary showed that: in CM, evolution of the submerged delta was dominated by accretion in the area within $5 \mathrm{~m}$ isobath, with erosion in the area between $5 \mathrm{~m}$ and $10 \mathrm{~m}$ isobath, and constant erosion in the gully; evolution in the east and north section of HS was dominated by vertical deposition, excluding erosion in the section near the north guide jetty; evolution along the southeast section of JDS was relatively stable, which was thought to be a natural change, while that in the section near the south guide jetty fluctuated greatly; evolution in the three sections of $\mathrm{NH}$ was dominated by vertical deposition.

(3) The ESA of the $2 \mathrm{~m}$ and $5 \mathrm{~m}$ isobaths continued increasing, and the annual growth rate reached $10.42 \mathrm{~km}^{2} / \mathrm{yr}$ and $7.99 \mathrm{~km}^{2} / \mathrm{yr}$ during 1982-2010, but it showed complex variation in the different sub-regions; the ESA of the $10 \mathrm{~m}$ isobath decreased with a rate of -22.40 $\mathrm{km}^{2} / \mathrm{yr}$; the ESA of the $15 \mathrm{~m}$ isobath changed slightly and remained relatively stable. In the four important sub-regions: the ESA of the $2 \mathrm{~m}$ isobath in HS and JDS increased, which was the opposite of that in CM and $\mathrm{NH}$; the ESA of the $10 \mathrm{~m}$ isobath remained stable, and erosion appeared to different degrees; the ESA of the $15 \mathrm{~m}$ isobaths changed slightly in CM, and that in the other sub-regions continued expanding outward at a low speed.

(4) The four main sub-regions showed sensitive but different responses to the changes of sediment load. A correlation could be seen between the sediment load at Datong Station and the area variation in $\mathrm{CM}$ and the $10 \mathrm{~m}$ isobath, which was distinguished from the other sub-regions, where important estuarine projects are located. Engineering sites such as the Deep-Water Channel and the large-scale reclamation project, play an important role in controlling the erosion-accretion evolution in areas within the $15 \mathrm{~m}$ isobath, especially within 2 $\mathrm{m}, 5 \mathrm{~m}$ and $10 \mathrm{~m}$ isobaths, against a macro-background of a reduction in sediment load.

\section{Acknowledgements}

The authors are grateful to Professor Xu Shiyuan of School of Geographic Sciences, East China Normal University, China, and Professor Yu Zhiying of State Key Laboratory of Estuarine and Coastal Research, East China Normal University, China, who gave us great help on this research and constructive advice to the paper.

\section{References}

Adrain S, Sebastian D, Viorel G U, 2007. Coastal changes at the Sulina mouth of the Danube River as a result of human activities. Marine Pollution Bulletin, 55: 555-563.

Anfuso G, DelPozo, J A M, 2005. Towards management of coastal erosion problems and human structure impacts using GIS tools: Case study in Ragusa Province, Southern Sicily, Italy. Environmental Geology, 48: 646-659.

Bao Q F, Ren G H, 2013. Strategy research on urban new space development and new deepwater port in Hengsha. Engineering Science, 15(6): 14-19.

Blum M D, Roberts H H, 2009. Drowning of the Mississippi Delta due to insufficient sediment supply and global sea-level rise. Nature Geoscience, 2: 488-491.

Carriquiry J D, Sánchez A, Camacho-Ibar V F, 2001. Sedimentation in the northern Gulf of California after cessation of the Colorado River discharge. Sedimentary Geology, 144(1/2): 37-62.

Chen J Y, 1988. Comprehensive Survey Report of the Coastal Zone and Tidal Land Resources in 1982. Shanghai: Shanghai Science and Technology Press. (in Chinese)

Chen J Y, Zhu H F, Dong Y F et al., 1985. Development of the Changjiang Estuary and its submerged delta. Continental Shelf Research, 4 (1/2): 47-56. 
Chen X, Zhang E, Mu H et al., 2005. A preliminary analysis of human impacts on sediment loads from the Yangtze, China, into the sea. Journal of Coastal Research, 21(3): 515-521.

Cui BL, Li XY, 2011. Coastline change of the Yellow River Estuary and its response to the sediment and runoff (1976-2005). Geomorphology, 127: 32-40.

Dai Z J, Liu J T, Fu G et al., 2013. A thirteen-year record of bathymetric changes in the North Passage, Changjiang (Yangtze) Estuary. Geomorphology, 187: 101-107.

Ding P X, Li S G, 2013. Planning ideas and key technology for building excavated-in harbor basin in the Hengsha Shoal of the Yangtze Estuary. Journal of East China Normal University: Natural Science, (4): 1-9. (in Chinese)

Fan D D, Kuang C P, Liu S G et al., 2013. Impacts of mega-engineers in Changjiang River catchment on coastal land reclamation and wetland conservation. Journal of Tongji University: Natural Science, 41(3): 458-464. (in Chinese)

Fanos A M, 1995. The impact of human activities on the erosion and accretion of the Nile delta coast. Journal of Coastal Research, 11: 821-833.

Finkl C W, 1994. Coastal hazards: Perception, susceptibility and mitigation. Journal of Coastal Research, 12(Special Issue): 372.

Frihy O E, Dewidar K M, 2003. Pattern of erosion/sedimentation, heavy mineral concentration and grain size to interpret boundaries of littoral sub-cells of the Nile Delta, Egypt. Marine Geology, 199: 27-43.

Hayashi S J, Murakami S G, Xu K Q et al., 2008. Effect of the Three Gorges Dam Project on flood control in the Dongting Lake area, China, in a 1998-type flood. Journal of Hydro-environment Research, 2: 148-163.

Hu H B, Zhan Y L, 2011. Visualization of river channel evolution of the South Branch in Yangtze Estuary supported by GIS. Procedia Environmental Sciences, 10: 1899-1903.

Ji N, Cheng H Q, Yang Z Y et al., 2013. Sedimentary and morphological evolution of nearshore coast of Yangtze Estuary in the last 30 years. Acta Geographica Sinica, 68(7): 945-954. (in Chinese)

Kuang C P, Liu X, Gu J et al., 2013. Numerical prediction of medium-term tidal flat evolution in the Yangtze Estuary: Impacts of the Three Gorges project. Continental Shelf Research, 52: 12-26.

Li P, Yang S L, Dai S B et al., 2007. Accretion/erosion of the subaqueous delta at the Yangtze Estuary in recent 10 years. Acta Geographica Sinica, 62(7): 708-714. (in Chinese)

Liu Y Y, Zhang X N, Xu S Q et al., 2010. Analysis on erosion-deposition of foreshore landforms of the Yangtze River Estuary. Resources and Environment in the Yangtze Basin, 19(11): 1314-1321. (in Chinese)

Lu X X, Higgitt DI, 2001. Sediment delivery to the Three Gorges 2: Local response. Geomorphology, 41: 157-169.

Milliman J D, 1997. Blessed dams or damned dams? Nature, 388: 325-326.

Milliman J D, Farnsworth K L, 2011. River Discharge to the Coastal Ocean: A Global Synthesis. New York: Cambridge University Press.

Nilsson C, Reidy C A, Dynesius M et al., 2005. Fragmentation and flow regulation of the world's large river systems. Science, 308: 405-408.

Syvitski J P, Kettner A J, Overeem I et al., 2009. Sinking deltas due to human activities. Nature Geoscience, 2: 681-686.

Trenhaile A S, 1997. Coastal Dynamics and Landforms. Oxford: Clarendon, pp.365.

Wan Y Y, Gu F F, Wu H L et al., 2014. Hydrodynamic evolutions at the Yangtze Estuary from 1998 to 2009 . Applied Ocean Research, 47: 291-302.

Wang Y H, Ridd P V, Wu H L et al., 2008. Long-term morphodynamic evolution and the equilibrium mechanism of a flood channel in the Yangtze Estuary (China). Geomorphology, 99: 130-138.

Xie W H, Yang S L, 1999. Evolution of the Jiuduansha shoal and its influence on adjacent channels in the Changjiang Estuary. China Ocean Engineering, 13(2): 185-195.

Yang S L, 1999. A study of coastal morphodynamics on the Muddy Islands in the Changjiang River Estuary. Journal of Coastal Research, 15(1): 32-44.

Yang S L, Belkin I M, Belkina A I et al., 2003. Delta response to decline in sediment supply from Yangtze River: Evidence of the recent four decades and expectations for the next half-century. Estuarine, Coastal and Shelf Science, 57: 689-699.

Yang S L, Milliman J D, Li P et al., 2011. 50000 dams later: Erosion of the Yangtze River and its delta. Global and Planetary Change, 75: 14-20.

Yang S L, Zhang J, Zhu J et al., 2005. Impact of dams on Yangtze River sediment supply to the sea and delta wetland response. Journal of Geophysical Research, 110. doi: 10.1029/2004JF000271.

Yu Z Y, Zhang Z L, Jin L et al., 2013. Morphological stability analysis of the planned excavated-in harbor and its channel in the Hengsha Shoal of the Yangtze Estuary. Journal of East China Normal University (Natural Science), (4): 55-71. (in Chinese)

Yun C X, 1983. Scouring and siltation processes of tidal flats of the Yangtze River Estuary and sediment exchange between flats and channels. Journal of Sediment Research, (4): 43-45. (in Chinese)

Yun C X, 2004. Recent Developments of the Changjiang Estuary. Beijing: China Ocean Press. (in Chinese) 